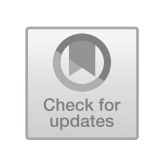

\title{
Stories of Relationship Between the Countries: "Harmony Is Most Important in the Implementing of Regulations"
}

\section{The China-Iran Friendship on the Silk Road}

This will be my first trip to Iran, yet like many other Chinese, I do not feel like a stranger in your ancient and beautiful country, thanks to the Silk Road that linked our two great nations for centuries and to the many legendary stories of our friendly exchanges recorded in history books.

Over 2,000 years ago, during the Western Han Dynasty in China, the Chinese envoy Zhang Qian's deputy came to Iran and received a warm welcome. Seven centuries later, during the Tang and Song dynasties, many Iranians came to China's Xi' an and Guangzhou to study, practice medicine and conduct business. In the thirteenth century, the famous Iranian poet Saadi wrote about his unforgettable travel to Kashgar, Xinjiang. In the fifteenth century, a renowned Chinese navigator, Zheng He, from the Ming Dynasty led seven maritime expeditions that took him to Hormuz in southern Iran three times. The much-prized Persian carpet is woven out of a fusion of China's silk and Iran's sophisticated techniques, and the exquisite blue and white porcelain is produced - thanks to a mixture of Iran's "smaltum" (a type of material containing cobalt, unique to Iran) and China's advanced skills. Via Iran, China's lacquerware and pottery as well as papermaking, metallurgy, printing, and gunpowder-making skills were spread to the west end of Asia and further on to Europe. From Iran and Europe, 
pomegranates, grapes, olives as well as glass, gold, and silverware were introduced to China.

- Work Together for the Bright Future of China-Iran Relations, a signed article on Iranian media (January 21, 2016).

\section{Commentary}

Like China, Iran is also an ancient civilization with a history of over 5,000 years. Ancient Iran was a place that had to be passed through on both the Silk Road and the Maritime Silk Road. Today, with a territory spreading all the way to the Caspian Sea in the north and to the Persian Gulf in the south, Iran stands by the Hormuz Strait - the intersection of "The Belt and Road", holding the "throat" of the maritime traffic artery of the Middle East.

The exchanges between China and Iran date back to the second century BC. According to Records of the Historian-Biography of Ferghana, Zhang Qian was dispatched to the Western Regions as an envoy twice, in $138 \mathrm{BC}$ and $119 \mathrm{BC}$, pioneering the Silk Road. On his second trip to the Western Regions, he dispatched his deputy Gan Ying and a team to the Parthian Empire (now Iran) from Quici (now Kuqa, Xijiang) via the Seleucid Empire (now Iraq), and the envoy from the Han court received a warm welcome from the Parthian King, who led a 20,000-people cavalry lined up to greet him. Due to the unceasing exploration from the Eastern Han Dynasty through the Tang Dynasty, the "Silk Road" eventually reached the Mediterranean coast in Europe, with the part within the territory of Tang stretching westward from Chang'an, the capital of Tang, to Yangguan by way of Hexi Corridor and the region outside the territory of Tang spanning Iran.

It almost seemed that our two countries were simply a camel ride or a boat trip away from each other. Indeed, the thousand-mile-long land and Maritime Silk Roads made it possible for China and Iran, two ancient civilizations, and their peoples, to embrace and befriend each other. As Saadi wrote, "Those who are far away and are of times long past deserve to be cherished more." Saadi is to Iran what Du Fu is to China. As "the greatest classical writer of Persia", Saadi has been a model of Persian literature for hundreds of years. Due to the China-Iran exchanges, people created works of art like the Persian carpet and blue and white porcelain. They gave 
poets inspiration while promoting cultural and people-to-people exchanges between the two countries.

The Middle East tour was Xi Jinping's first state visit in 2016, which confirmed that $\mathrm{Xi}$ had already left his diplomatic footprints all over the world since the 18th National Congress of the Communist Party of China. All three countries to which he paid state visits at this time are China's important partners and ardent supporters in the "The Belt and Road" initiative. As Xi said, today the relationship between China and the Middle Eastern countries is having a new start that features the spirit of peace, cooperation, openness, inclusiveness, mutual learning, and mutual benefit; thus, we should draw on our past progress and chart a new course for the future. The historical story shared by $\mathrm{Xi}$ in his speech set the tone for the renewed embrace of the two ancient civilizations.

In ancient times, our two countries maintained a friendship through the exchange of needed goods; today, we share one vision on "The Belt and Road". In the past, China and Iran made important contributions to opening of the Silk Road and by promoting exchanges between Eastern and Western civilizations. The China-Iran friendly exchanges for more than 40 years of diplomatic relations have continued to embody the Silk Road's spirit of peace, cooperation, openness, inclusiveness, mutual learning, and mutual benefit. Hassan Rouhani, the Iranian President, said, "President $\mathrm{Xi}$ is the first foreign state head to visit Iran after the settlement of the Iranian nuclear issue. This reflects the high level of positive relations and friendship between Iran and China." In the speech, Xi Jinping, taking the pomegranate introduced from Iran to China as an example, expressed his new expectations for China-Iran relations and his hope for even more fruitful cooperation between our two countries.

\section{A Memorial Statue of Deng Xiaoping}

How time flies! As we look back on the history of China-Singapore relations, we cherish all the more the memory of two great statesmen who forged this relationship, Mr. Deng Xiaoping and Mr. Lee Kuan Yew. Five years ago, on another visit to Singapore, I joined Mr. Lee Kuan Yew in unveiling a commemorative marker in honor of Mr. Deng Xiaoping on the bank of the Singapore River. Although both of them are no longer with us, their great achievements will always be remembered. 
- Forging a Strong Partnership to Enhance Prosperity of Asia-Speech at the National University of Singapore (November 7, 2015).

\section{Commentary}

On the banks of Singapore, there is a memorial statue of Deng Xiaoping. It is a half-length statue produced by the famous sculptor Li Xiangqun. While gazing at the statue, we can see fortitude from Deng Xiaoping's amiable face, the impression that he is musing on something or is somewhere far away. His well-known saying, "Development is of overriding importance," is displayed on the back of the statue.

Deng Xiaoping first set foot in Singapore and stayed there for 2 days more than 90 years ago on his way to France to study and work. He formed lasting ties with Singapore in those 2 days. In 1978, when the surge of China's reform and opening up was brewing, Deng Xiaoping once again stepped on that soil. During his visit, he congratulated Lee Kuan Yew on "the changes of Singapore", and he received Lee's recognition that China undoubtedly had the ability to catch up with and even surpass Singapore. "We came from the later generations of peasantry from Fujian, Guangdong and other provinces in China, those who neither knew a single word nor had any farmland. However, they (the Chinese) have countless compatriots who were the dignitaries and scholars who remained to guard the Central Plains," Lee explained. After hearing that, Deng did not speak. In the famous South Talks in 1992, Deng Xiaoping further proposed, "We should learn from Singapore's experience."

With the consent of the governments of both countries, the epigraph outlines Deng's life story, the relationship between him and China's reform and the special role he played in the relationship between China and Singapore. "In his famous 1992 South Talks, Deng Xiaoping spoke of Singapore's well-managed and orderly society. Since then, many Chinese officials have been sent to Singapore for training. Over the years, the two countries have frequently exchanged high-level visits, enhancing economic cooperation, expanding people-to-people and cultural exchanges, and further deepening bilateral relations," the epigraph states.

On November 14, 2010, when the evening lights were lit, Xi Jinping, China's then Vice-President, and Lee Kuan Yew ended the talks and walked along the verdant lane of rain trees to attend the unveiling ceremony of the statue that was being held on the riverbank. 
On November 7, 2015, Xi Jinping visited Singapore on the occasion of the 25th anniversary of the establishment of diplomatic relations between China and Singapore. In his speech at the National University of Singapore, he recalled the two great men, Deng Xiaoping and Lee Kuan Yew, and he recollected the scene when he unveiled the memorial statue of Deng Xiaoping 5 years before. His affectionate words recall to our minds the road to China-Singapore cooperation, which has advanced with the times. "China has drawn on the Singaporean practices in addressing tough challenges encountered in its reform and development endeavors. For its part, China's development has also created tremendous opportunities for Singapore's development." Xi added that with the concerted efforts of our two peoples as well as increasing political mutual trust and deepening practical cooperation between the two countries, the China-Singapore relationship will surely make even greater progress, and our two countries will surely enter a new era.

\section{How Faithful Are China and Pakistan to Each OTHER}

In 2008, when the devastating earthquake struck Wenchuan, China, Pakistan responded immediately and sent all its transport aircrafts to ship its entire reserve of tents to China. The Pakistani medical team on the transport plane had to remove all of the seats to make room for the tents, and they sat on the floor all the way to China. Today, thousands of Pakistanis are working side-by-side with Chinese engineers and workers on projects undertaken by China in Pakistan, and there are many moving stories about their cooperation.

Similarly, whenever Pakistan has been in need, China has come to its help. China firmly supports Pakistan's efforts to uphold the sovereignty, independence, and territorial integrity. When Pakistan was hit by a severe flood in 2010, China provided immediate relief assistance via air and land routes. We dispatched the largest ever medical team and sent a large convoy of vehicles and helicopters to carry out rescue operations, the first time that such an operation was undertaken in the history of China's rescue assistance. Following the terrorist attack in Peshawar at the end of 2014, China invited the students who had been injured in the attack and their families to spend some time in China to recuperate so the trauma those kids had experienced could be healed with the care and love of the Chinese people. 
In the most recent evacuation mission in Yemen, the Chinese navy evacuated 176 Pakistanis from the Port of Aden, and the Pakistani navy evacuated eight Chinese students from Mukalla Port. The Pakistani commander gave the order that the ship would not leave until all the Chinese students were on board. His stirring words again show that the China-Pakistan friendship is indeed deeper than the sea.

- Building a China-Pakistan Community of Shared Destiny to Pursue Closer Win-Win Cooperation-Speech at the Parliament of Pakistan (April 21, 2015).

\section{Commentary}

China and Pakistan are close to each other in both geography and emotion, and they have close ties in their interests. Pakistan was the first Islamic state to establish diplomatic relations with new China, with the diplomatic relations being established as early as May 21, 1951. Chinese leaders have described the unswerving friendship between China and Pakistan as "higher than mountains and deeper than oceans", and our Pakistani friends further enrich the description with two more "thans"- "sweeter than honey and stronger than steel".

"It is better to give up gold than betray the China-Pakistan friendship." This is a famous saying in Pakistan. Following the devastating earthquake that struck Wenchuan on May 12, 2008, the then Pakistani President Pervez Musharraf visited the Chinese embassy in Pakistan and expressed his sincere condolences to the Chinese people. As "China's staunch ally", Pakistan exhausted almost all it had to help China. It "sent all its transport aircrafts to ship its entire reserve of tents to China", and it kept the cost of the tents secret from China- "The aid should not be measured in terms of money. Did our Chinese brother charge us for the help they had provided for us?"

As a Chinese saying goes, "Strong wind reveals the strength of the grass, and genuine gold withstands the test of fire." When Pakistan is in need, China has also come to its help. In July 2010, a severe flood hit Pakistan, with one-fifth of the country, a population of 20 million, being affected for nearly 3 months and the economic losses reaching more than 10 billion US dollars. As a quick response to the disaster, China dispatched its largest ever medical team. Braving the heat, the medical personnel waded through 
the water to treat the injured people. Some of them even got sunstroke, yet they again threw themselves into the relief work having barely finished receiving fluid infusions. Some medical personnel drank up to 15 bottles of water per day because of the heat. In December 2014, the Pakistani Taliban waged a terrorist attack in the Peshawar Army Public School, causing 141 deaths among the teachers and students. "The coffins are too distressing to lift up, even the smallest one." China immediately condemned the attack and provided immediate assistance for Pakistanis, and it even invited two groups of injured students and their families to spend some time in China to recuperate. Under the arrangement of China, they visited Beijing, Shenzhen, Hong Kong, Guangzhou, and some other Chinese cities, enabling them to "get a taste of Chinese history, culture and development and feel the profound friendship between the Chinese and Pakistani peoples."

Chinese people call their true friends "faithful friend" and Pakistan has always been such a "faithful friend" of China. A Pakistani leader once said, "If anyone wonders how friendly two countries can be with each other, he should learn from the relationship between China and Pakistan." Pakistan is a country whose primary school textbook includes the words, "China is a staunch ally of Pakistan", and Pakistan is known as the one and only "all-weather strategic cooperative partner" of China.

"Meeting a good friend for the first time is like having a reunion with an old friend." This was what Xi Jinping said about his first visit to Pakistan. He also said, "Although this is my first visit to your country, Pakistan is not at all unfamiliar to me." "The moment we arrived in your beautiful country, my colleagues and I have been overwhelmed by your warm hospitality. It is just like coming to the home of dear brothers," he added. During the visit, Xi, President Hussain, as well as Prime Minister Sharif, agreed to elevate China-Pakistan relations to "an all-weather strategic cooperative partnership".

In Pakistan's parliament, Xi gave an affectionate account of the governmental intercourse and people-to-people exchanges between China and Pakistan, which demonstrated that the friendship between China and Pakistan is based on trust and mutual support, and we are devoted friends going through both good and hard times. His words also showed that our two countries will always move ahead together, rain or shine. Meanwhile, he asserted that China will always maintain its relationship with Pakistan from a strategic and long-term perspective, and he gives Pakistan high priority on its diplomatic agenda. He also substantiated the China-Pakistan community's shared destiny through five positions. In his speech, Xi also 
expressed his expectation by citing what the former Chinese Ambassador to Pakistan, Geng Biao, for whom he had once worked, has said, "The traditional friendship between China and Pakistan will spread far and wide, just like the Karakoram Highway."

\section{Newtonian Mechanics}

I know Ms. Chancellor is a Doctor of Physics. Thus, I have thought about how to better promote China-Germany relations on the basis of Newton's three laws of motion. First, we should firmly capitalize on the "inertia" of China-Germany cooperation. Cooperation is the main theme of the relationship between China and Germany, and it is what our two countries should unwaveringly strive for. We should continue to strengthen high-level exchanges and give full play to the mechanisms of government consultation and strategic dialog to continuously enhance strategic mutual trust. Second, we should deepen the practical cooperation between the two countries to promote the "acceleration" of the development of China-Germany relations. Today, China is carrying out the policy of promoting adjustment through reform to promote development through adjustment. We are confident that we will achieve sustained and sound economic development, thus creating more opportunities for China-Germany cooperation. Our two countries should strengthen our sense of partnership and opportunity, and in the spirit of mutual benefit and joint development, we should continue to expand our intertwined interests and deepen practical cooperation in an all-round way. Third, we should reduce the "reactive force"in the development of our bilateral relations. We should focus on common interests, seek common interests while reserving minor differences, and reduce resistance to the development of bilateral relations.

- Talk with German Chancellor Merkel in Saint Petersburg (September $6,2013)$.

\section{Commentary}

Born in 1643, Newton was a famous English physicist who was regarded as an "encyclopedic genius". His book Philosophic Naturalis Principia Mathematica published in 1687 was a masterpiece that epitomized the first scientific revolution. The explanation of universal gravitation and the three 
laws of motion was the basis on which all scientific views in physics were proposed during the following three centuries, and it is the foundation of modern engineering science.

During the Eighth Leaders' Summit of the G20 held in Saint Petersburg, Russia, in September 2013, Xi Jinping met German Chancellor Merkel and used Newton's three laws of motion to illustrate the general direction of as well as the new opportunities and potential problems facing China-Germany relations.

Obtaining a doctorate in physics from the University of Leipzig, Merkel worked as a science researcher before entering politics. Xi's use of Newtonian mechanics as a metaphor not only was a reasonable application of Western culture but it also represented his respect for Merkel's learning and cultivation. $\mathrm{Xi}$ offered another metaphor: "Developing the relationship between China and Germany is like driving a car. We must look ahead to make the trip safe and smooth. As long as our two countries enrich the fuel and hold the steering wheel properly, the car of China-Germany cooperation will certainly run fast and steady and head for a bright future." Only if we make a blueprint for the development of our bilateral relations in a more macro- and long-term perspective can we drive the car faster and better.

\section{“A River Runs Deep Because of Its Source”}

As an African saying goes, "A river runs deep because of its source." The friendly exchanges between China and Africa date back a long time. In the 1950s and 60s, the first-generation leaders of new China-Mao Zedong, Zhou Enlai, and others-and African statesmen of the older generation ushered in a new epoch in China-Africa relations. Since then, the Chinese and African people have sincerely supported and closely cooperated with each other to fight against colonialism and imperialism and achieve national independence and liberation in the pursuit of development and national revival. A fraternal bond has been formed in this process, which has seen us through thick and thin.

- Trustworthy Friends and Sincere Partners Forever-Speech at the Julius Nyerere International Convention Center (March 25, 2013). 


\section{Commentary}

Although China and Africa are far apart, the friendly exchanges between them date back a long time and appear high-powered, with similar historical experiences, China and Africa have always shown compassion for and supported each other to achieve national liberation, during which time they have built a deep friendship and became good friends in good times and bad.

During the African people's struggle for national independence in the 1950s and 1960s, China stood firmly by them and fully supported their righteous struggle against colonialism and imperialism and for national independence. Mao Zedong once made it clear that, "to do our jobs and to make friends", we should focus on "three continents: Asia, Africa and Latin America".

From December 1963 to February 1965, Zhou Enlai paid three state visits to Africa with his visiting delegations, leaving his footprints in ten African countries. These visits began the construction of a new type of China-Africa relationship and laid the groundwork for China-Africa friendship that has lasted for over 50 years. During the visits to Egypt and Algeria, Zhou Enlai put forward the five principles for developing China's relations with African and Arab countries. These principles laid the foundations for China-Africa exchanges, based on which the two sides built a new type of relationship that advocated mutual understanding and mutual support. The exchanges between China and Africa can be described as equal and sincere, setting a good example in the history of international relations.

The African people have also given strong support and selfless assistance to the Chinese people. In October 1971, the 26th Session of the UN General Assembly passed a resolution to restore the lawful seat of the People's Republic of China in the UN. Eleven of the 23 sponsor countries were African countries, and 26 among the 76 affirmative votes were from Africa. China has also received strong support from the overwhelming majority of African countries on a number of major issues. For example, they helped China defeat anti-China bills on the human rights situation in China and proposals for Taiwan's participation in the UN, and they supported China's accession to the WTO and China's bid for the Olympic Games.

Over the past half-century and thereafter, the friendly and cooperative relationship between China and Africa has been tested by the years and has 
continuously been consolidated and developed. Currently, 52 of Africa's 54 countries have established diplomatic relations with China.

On March 24, 2013, Xi Jinping arrived at Julius Nyerere International Airport, Tanzania, and began his 26-hour state visit to the East African country. This was Xi Jinping's first trip to Africa as Chinese President, and it was his sixth trip to Africa. In the important speech at the Julius Nyerere International Convention Center, Tanzania, he described the long-standing China-Africa friendship to demonstrate that China-Africa relations did not develop overnight. Neither are they a gift from someone else. They have been nurtured and built, step by step, by our two sides over the years.

"Friends are as good as their word; they travel a thousand li to keep a rendezvous." In this important speech, Xi also made a concise proposition to further develop the China-Africa relationship: first, in treating African friends, we stress the importance of "sincerity"; second, in conducting cooperation with Africa, we stress the importance of "real results"; third, in strengthening the China-Africa friendship, we stress the importance of "affinity"; fourth, in resolving problems that may arise in cooperation, we stress the importance of "good faith". This proposition vividly illustrated the essence of China-Africa relations: sincerity, friendship, mutual respect, equality, mutual benefit, and common development. Although separated by vast oceans, China and Africa share a strong empathy with each other.

\section{The TAZARA Was Constructed by Friendship}

More than 40 years ago, over 50,000 Chinese brothers and sisters came to Africa with their devotion to the African people. They fought side-byside with the brothers and sisters of the people of Tanzania and Zambia, overcoming various difficulties and completed the construction of the Tanzania-Zambia Railway (TAZARA), known as the railway of friendship and the railway of freedom, with their sweat, their blood, and even their lives. More than 60 of them sacrificed their precious lives on this piece of land far away from home. They translated the great spirit of internationalism with their lives. They are the heroes who cast the monument of China-Tanzania and China-Africa friendship. Their names, just like TAZARA, will always be remembered in the hearts of the Chinese, Tanzanian and Zambian people.

- Speech During the Visit to the Cemetery for Memorable Deceased Chinese Experts Assisting Tanzania (March 25, 2013). 


\section{Commentary}

At a cemetery in the southwestern suburb of Dar es Salaam, literally, "The residence of peace", 69 Chinese compatriots who sacrificed their lives while assisting Tanzania in its construction were buried. At the cemetery, the grass looks like a green carpet, the green pine trees and Delonix regia stand high and straight. A huge stela is inscribed with red lettering: "Cemetery for Memorable Deceased Chinese Experts Assisting Tanzania" in both Chinese and English.

Since the 1960s, China has sent tens of thousands of experts to Tanzania and made selfless contributions to the economic construction of this African country in various fields. Among the 69 sacrificed compatriots, some helped the Tanzanian people build coal mines, develop agriculture, or cultivate water conservancy; however, most of them sacrificed their lives constructing the Tanzania-Zambia Railway (TAZARA).

TAZARA is an outstanding symbol of China-Africa friendship. From May 1968, when the first Chinese exploring team stepped into the boundless wilderness overgrown with grass to route the railway, to July 1976, when TAZARA was officially open to traffic, more than 50,000 Chinese engineering technicians made enduring contributions to the construction of the railway. Going through hardships and dangers, engineering technicians from China, Tanzania, and Zambia opened up a 1,860-kilometer railway that crossed the towering mountains. As the economic artery connecting Tanzania and Zambia as well as other African countries, this railway has created favorable conditions for the economic development of the two countries and supported the struggle for national liberation in southern Africa, thus being honored as "the road of freedom" and "the road of liberation" by the two peoples.

Zhang Mincai, a hydraulic expert buried in the Cemetery for Memorable Deceased Chinese Experts Assisting Tanzania, was the first Chinese expert to sacrifice his life in assisting Tanzania. In the search and exploration for drinking water for the local people in the bush, in October 1967, Zhang Mincai was attacked by a swarm of wild bees. After being informed of this, Premier Zhou Enlai immediately sent a doctor from China to rescue him; however, the doctor was unable to save his life, and Zhang Mincai died at the age of 35 .

By paying a tribute to the memory of the late Chinese experts assisting Tanzania and telling the stories of the friendly cooperation between China 
and Africa with deep emotion, Xi Jinping expressed his wish to carry forward the spirit of the TAZARA and to treasure and cherish the tradition of friendship between China and Africa. In Xi's first overseas trip as Chinese President, he paid a visit to Africa, which he described as "a continent full of promise". This reflected China's consistent brotherhood with developing countries. In strengthening the China-Africa friendship, we stress the importance of "affinity". Through the story, Xi proclaimed to the world that the friendly exchanges between China and Africa are not based on certain conditions, but rather, they are supported by their thick-and-thin friendship. As Charles Sanga, Tanzania's former ambassador to China, said, "Xi Jinping's sheer joy stirred by the continuous development of the African continent is so sincere and moving. It is love from the bottom of his heart."

\section{“Golden Keys” from Muscatine}

This afternoon, I will go to visit Iowa, which will be my second visit to the state in 27 years. I am going to tell my old friends there that the "golden keys" that the representative of Muscatine City Hall presented to us 27 years ago symbolized the opening of local exchanges and cooperation between our two countries. And today, there are already 38 sister province/state relationships and 176 pairs of sister cities between our two countries. 47 out of the 50 American states have seen their exports to China grow several or even dozens of times over the past 10 years. This shows that once open, the door to local exchange and cooperation between China and the United States cannot be closed by any force. On the contrary, it will only open wider and wider.

- Work Together for a Bright Future of China-US Cooperative Partnership-Speech at Welcoming Luncheon Hosted by Friendly Organizations in the United States (15 February 2012).

\section{Commentary}

Muscatine is the county seat of Muscatine County, Iowa, in the United States. It is located along the Mississippi River. Agriculture and animal husbandry are its economic backbone, and it is especially famous for growing watermelons and producing mother of pearl buttons. 
In 1985, Xi Jinping, the then County Party Secretary of Zhengding, Hebei Province, led a delegation to Iowa and visited the small town of Muscatine to conduct an on-the-spot investigation of local agriculture and animal husbandry. When he visited the farms, he asked the farmers to demonstrate how to cultivate sweet potato seedlings in a greenhouse; when he lived with a local family, he took every opportunity to learn about America; after returning to China, he wrote a detailed report, which cited many comments by local Americans and made reference to the development of agriculture and animal husbandry in Zhengding. In the eyes of the American locals, Xi was a "very capable leader, always clear with what he wanted to know, always punctual and neatly dressed, and always showing burning curiosity." No matter where he went, he asked questions and consulted with those he met.

In February 2012, Xi Jinping, the then Chinese Vice President, revisited Muscatine. During his visit, US Iowa Governor Branstad and his wife; Vice Governor Reynolds and his wife; Muscatine's Mayor; the Dvorchaks, the landlords who had received Xi Jinping in 1985; and local high school student representatives gave Xi Jinping and his delegation a warm reception. The old friends said that Xi's visit bridged the past and future, renewed the special affinity and friendship established 27 years ago, and set an example for both the American and Chinese people. They hoped and believed that Xi's visit would provide an impetus to a better partnership between our two countries. During this visit, the Mayor of Muscatine presented another "golden key" to Xi; Xi was the first person to receive two "golden keys" in Muscatine's history.

"To me, you are America." These words of Xi will be forever in the minds of the Muscatine people. On September 17, 2015, Muscatine's Mayor Dwayne Hopkins named the house where Xi had stayed 30 years ago, the "Sino-US Friendship House", which is now open to the public in honor of China-US local cooperation and friendship. "This house is a symbol of friendship between China and the US," said Gary Dvorchak, son of the Dvorchaks. As one enters the "Sino-US Friendship House", one is embraced by a warm "Chinese flavor". One can also appreciate the group photos of $\mathrm{Xi}$ and his Muscatine friends on the walls and over the fireplace.

There is an old Chinese saying that "A new dress is better than an old one, but an old friend is more intimate than a new one." On February 15, 2012, Xi revisited the city of Muscatine, and he used this saying to describe his friendship with his former landlords, the Dvorchaks. Xi went on to say, "The American people are as simple, industrious, enthusiastic, and friendly 
as the Chinese people. There are many common interests between the two peoples, and they can surely become good friends and good partners in mutually beneficial cooperation." The story of the "golden keys", which he told at the welcome luncheon, not only reflects China's way of making friends - maintaining old friendship while renewing it-but it also highlights the importance of local exchange and cooperation between China and the United States.

Xi Jinping, who came up from the grassroots level, attaches great importance to cooperation and exchange with foreign countries. At the Third China-US Governors' Forum held in Seattle on September 22, 2015, he stressed that "state-to-state relations ultimately rely on the support of the people and serve the people" and that "provinces and states are closest to the people".

Open Access This chapter is licensed under the terms of the Creative Commons Attribution-NonCommercial-NoDerivatives 4.0 International License (http:// creativecommons.org/licenses/by-nc-nd/4.0/), which permits any noncommercial use, sharing, distribution and reproduction in any medium or format, as long as you give appropriate credit to the original author(s) and the source, provide a link to the Creative Commons license and indicate if you modified the licensed material. You do not have permission under this license to share adapted material derived from this chapter or parts of it.

The images or other third party material in this chapter are included in the chapter's Creative Commons license, unless indicated otherwise in a credit line to the material. If material is not included in the chapter's Creative Commons license and your intended use is not permitted by statutory regulation or exceeds the permitted use, you will need to obtain permission directly from the copyright holder.

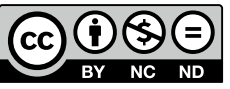

